\title{
How robust is the UTAUT theory in explaining the usage intention of e-government services in an unstable security context?: A study in Iraq
}

\author{
Abdullah Kaid Al-Swidi* \\ Department of Management and Marketing, \\ College of Business and Economics, \\ Qatar University, \\ P.O. Box 2713, Doha, Qatar \\ Email: swidi@qu.edu.qa \\ *Corresponding author

\section{Munadil K. Faaeq} \\ School of Business Management, \\ College of Business, \\ Universiti Utara Malaysia, \\ 06010, Sintok, Kedah, Malaysia \\ Email: munadil@uum.edu.my \\ Email:munadelaa@gmail.com
}

\begin{abstract}
This study aimed to examine the robustness of the unified theory of acceptance and use of technology (UTAUT) theory in explaining the usage of electronic government services in an unstable security context. In addition, it attempts to investigate the extent to which usage behaviour could create continued usage intention among the citizen's. The data were collected from employees in public universities in Iraq employing a survey questionnaire. Out of 700 questionnaires distributed, 436 usable questionnaires were returned. The partial least squares structural equation modelling (PLS-SEM) was employed to test the validity and reliability of the model and to examine the hypothesised relationships. The findings of the study confirmed the robustness of UTAUT theory and its validity in explaining behaviour in an unstable security context. In addition to examine how robust is the UTAUT theory in examining the behaviour in using electronic government eG services, it also extends the UTAUT model to examine future continued usage of the eG services and how UTAUT variables could shape this behavioural intention.
\end{abstract}

Keywords: electronic government; eG; effort expectancy; performance expectancy; social influence; facilitating conditions; perceived instability.

Reference to this paper should be made as follows: Al-Swidi, A.K. and Faaeq, M.K. (2019) 'How robust is the UTAUT theory in explaining the usage intention of e-government services in an unstable security context?: A study in Iraq', Electronic Government, Vol. 15, No. 1, pp.37-66.

Biographical notes: Abdullah Kaid Al-Swidi is an Associate Professor of Management in the Department of Management and Marketing, College of Business and Economics, Qatar University. He obtained his Master's of Statistics and Operations Research from India and Doctor of Business 


\begin{abstract}
Administration from Malaysia. His teaching focus is on operations and quality management, innovation and MIS and business analysis. So far, he has supervised more than $15 \mathrm{PhD}$ students working on different fields such as business excellence and quality management just to mention a few. His research work has been published in various international peer reviewed journals. In addition to his teaching and research oriented activities, has been a professional trainer and business consultant for companies and programs in Qatar, Malaysia and Yemen.
\end{abstract}

Munadil K. Faaeq received his BSc in Public Administration from the Baghdad University, Iraq in 2002-2003. Also, he received his Master of Business Administration (MBA) in 2008 and $\mathrm{PhD}$ in Management Information System from the Northern University of Malaysia in 2014. Currently, he is also serving as a Visiting Senior Lecturer in SBM/UUM Malaysia. Moreover, he was appointed to be the Chairman of the Innovation and Creativity Committee in the School of Business Management since 2017 and also as a Consultant of Innovation and Commercialisation Center. $\mathrm{He}$ is a member of Institute of Electrical and Electronics Engineers (IEEE).

\title{
1 Introduction
}

The evolution of information and communication technologies (ICTs) witnessed the emergence of electronic government (eG) in the late 1990s (Alsohybe, 2007; Alruwaie 2012). Since then, $\mathrm{eG}$ has become an important application used by government agencies worldwide to facilitate communication and interactions with employees and citizen's, between agencies, and with businesses (AlShihi, 2006; Berlilana et al., 2017; Carter and Bélanger, 2005; Krishnan et al., 2017).

eG was defined by The World Bank Group (2002) as the new way of interaction between governments and their citizen's using the ICT technology such as internet, networks and mobile computing advancements. In a simpler term, eG can be defined as using ICT in the public sector to offer electronic services through the use of the internet. In the field of information systems (IS), researchers following eG development indicated that $\mathrm{eG}$ has become a very interesting and evolving research area with a high level of importance (Berlilana et al., 2017; Carter and Bélanger, 2005; Krishnan et al., 2017; Mofleh and Wanous, 2008). Evolving over more than two decades, eG services have continued to expand around the world (Berlilana et al., 2017; Carter and Bélanger, 2005; Krishnan et al., 2017).

\section{1 eG types services}

More specifically, eG offers services to its citizen's perform all the needed transactions electronically (Davison et al., 2005). These services depend on the users' needs and the ICT infrastructure and capacity. This diversity has led to the development of different types of $\mathrm{eG}$ application such as government-to-employees (G-2-E), government-to-government (G-2-G), government-to-business (G-2-B) and government-to-citizen (G-2-C) interactions. G-2-E service is an automated government database system that makes it possible to maintain and distribute personal information. 
G-2-G service is a customised electronic cooperation between the government organisations. G-2-B service is an electronic collaboration between the government and business organisations (Shamsuddin et al., 2017; Tyshchenko and Grosse, 2008). G-2-C service is a way to use the web and government applications to communicate online with citizen's (Al-Sobhi et al., 2011). In its early stage of implementation (1990s), most government agencies focused on the implementation of G-2-E interactions, such as eleave and e-employment. In the 2000s, as the applications of eG became more sophisticated, the attention shifted from G-2-E applications to G-2-B and G-2-G applications (Holden et al., 2003; Moon and Norris, 2005). More recently, the G-2-C services have become high priority among other eG services (Berlilana et al., 2017; Hujran and Shahateet, 2010; Krishnan et al., 2017; Prima and Ibrahim, 2011). The importance of G-2-C is due to the efforts of all the governments to put all their services on the web to facilitate all the transactions of the citizen's and also to change the mode of interaction from the traditional services to the electronic services in the public sector in order to support the express development of technological modification (Alsohybe, 2007). Additionally, the democratic system is enhanced by the eG system through the simplicity it provides for the public as well as the officials. Recently, the importance of eG services has been realised by most of the developed countries to facilitate the interaction between government and its people and they have been fast to implement them (Alsohybe, 2007).

\section{2 eG projects and issues}

From another perspective, the early stage of eG implementation mostly concentrated in developed countries like Canada (Roy et al., 2015), parts of Europe (Graafland-Essers and Ettedgui, 2003), Turkey (Ozkan and Kanat, 2011), Netherlands (Horst et al., 2007), Singapore (Chan et al., 2008; Teo et al., 2009), the UK (Beynon-Davies and Williams, 2003; Griffin and Halpin, 2005; Hamilton et al., 2011), Taiwan (Hung et al., 2006; Chu et al., 2004) and the USA (Lee et al., 2003; Yun and Opheim, 2010). Similarly, developing countries, such as Malaysia, Indonesia, India and Bangladesh, also realised the importance of eG (Lean et al., 2009; Kumar and Best, 2006; Rokhman, 2011). In the early 2000s, Middle Eastern countries, such as the UAE, Saudi Arabia, Yemen, Sudan, and Oman, started implementing the eG applications (Abri, 2009; AlShihi, 2006; Alsohybe, 2007; Al-Sobhi et al., 2011; Abdalla, 2012). More specifically, there is a clear gap and lack of research in eG implementation and evaluating in the Middle East region and in particular countries experiencing conflict and violence (Khan et al., 2010a, 2010b, 2012) such as Iraq.

Despite the popularity of the adoption of eG services in developed and developing countries and the increasing attention that has been given to the sophistication of eG, researchers have found a high rate of failure in eG implementation (Aladwani, 2016). For example, for eG projects in developing and transitional countries, 35\% were total failures, 50\% were partial failures, and only 15\% were successful (Heeks, 2008). The failure rate of eG projects in developing countries as reported by the United Nations (2003) is estimated to be between $60 \%$ and $80 \%$, including statistics in most of the Middle Eastern countries. The report also indicates the lack of eG projects in Iraq (United Nations, 2004, 2005, 2008, 2012). 
As discussed earlier, the research regarding the adoption of eG applications has shown many discrepancies between developed and developing countries and between safe and conflict-filled countries (Alvesson and Karreman, 2007; Khan, 2010; Khan et al., 2012). Basu (2004) and Alruwaei (National Strategy and Action Plan E-Governance in Iraqi, 2012-2015) argue that circumstances such as conflicts, corruption, and wars may influence the usage and continuous usage intention of eG services in involved counties (Basu, 2004; Alruwaie, 2012). Some other countries with unstable environments such as Afghanistan, Burma, Colombia, Congo, Georgia, India, Iran, Iraq, Mexico, Myanmar, Nigeria, Pakistan, Philippines, Somalia, and Sri Lanka (HIIK, 2008; Top 10 Most Dangerous Countries in the World, 2013).

In addition, studies that examine the continued usage of eG are mostly conducted in a safe and stable environment (Bhattacherjee, 2001; Limayem et al., 2003; Wangpipatwong et al., 2008), but there is a paucity of studies examining the usage of eG services in risky and unstable environments. In eG implementation, many changes should be considered, including changes related to the transparency, legislative rules and participation of people in a particular country through the use of the internet (Alsohybe, 2007; Siau and Long, 2005). Due to these changes, eG finds resistance in many countries around the world, in general, and in countries with risk, conflicts, violence, and corruptions, in particular (Alsohybe, 2007; Basu, 2004; Evans and Yen, 2005; Khan, 2010; Khan et al., 2012).

Several researchers argue that the success of eG implementation is strongly contingent on the citizen's willingness to continue using these services (Alruwaie, 2012; Bhattacherjee, 2001; Limayem et al., 2003; Lawan, 2009; Park, 2008; Wangpipatwong, 2008). In other words, the eventual success of the implementation of any technology depends on its continued use rather than on first-time use (Bhattacherjee, 2001; Limayem et al., 2003; Wangpipatwong et al., 2008).

The difficulty to adopt and to continue using the eG found in many countries around the world is due to the processes and procedures. These governance processes have to be reengineered and aligned with the objectives and design of these applications (Alruwaie, 2012; Alsohybe, 2007; Ebrahim and Irani, 2005; Ma et al., 2005). Furthermore, if a system does not meet the user's needs and expectations, regardless of its success in the early phase of adoption, users may discontinue using the innovative system (Wangpipatwong et al., 2008).

Despite the bulk of literature investigated on the significant and important factors influencing citizen's (users') continued usage intention (CUI) of eG (Carter and Belanger, 2004; Phang et al., 2005; Wangpipatwong et al., 2008; Wang, 2002), these studies are still absent in the context of unstable environments.

More importantly, a careful review and analysis of the existing literature showed the importance of CUI in IS in general and in eG specifically (Alruwaie, 2012; Bhattacherjee, 2001; Limayem et al., 2003; Hong et al., 2006; Wangpipatwong et al., 2008; Chiu and Wang, 2008). Obviously, in the literature of eG, there is a lack of examining the effect of UB on the continuing usage intention in unstable environments. That is, a scarcity exists among the prior studies that examined the effect of CUI among online services usage behaviours (UBs) (Alruwaie, 2012).

In general, eG systems have been gaining in importance as a major component of the ICT systems provided by governments worldwide to facilitate all the transactions of the citizen's. This system has gained popularity in developed and developing countries alike. Despite the recognised importance of the eG system, researchers are still far away from reaching an agreement on the antecedents and consequences of $\mathrm{UB}$ of eG services. 
With all that in mind, the main purpose of this paper was to re-examine the exploratory power of unified theory of acceptance and use of technology (UTAUT) theory in explaining the adoption of eG services in a less security context. In addition, it investigates the effect of the $\mathrm{eG}$ services behaviour on the intention of continued usage of these services.

\section{3 eG services in Iraq}

Since 2003, eG projects have been initiated in most of the Iraqi government agencies as a step to improve the services provided to the public and to reform the administrative system. Specifically, the Ministry of Science and Technology (MOST) in Iraq has developed an eG portal, which provides many services, such as e-passport, e-scientific innovation form, e-license, e-fines, e-birth certificates, and e-death certificates. This eG portal has saved time and made citizen's lives more convenient (IRAQ e-GOV Portal, 2012). However, the Iraqi government is still seeking for the right eG model that could assist its eG projects and aid the delivery of information and services to the public and among government agencies efficiently in a short period of time. It is, however, argued by Al-Shafi and Weerakkody (2010) that the adoption of eG services by the Iraqi citizen's has been less than satisfactory. One of the main potential advantage of eG services is that they are hoped to help reduce corruption among government employees (Al-Mutmar, 2013).

As one of the countries with unstable security, Iraq has been suffering from a long-term internal crisis (conflicts and violence) that has led to a large loss of lives and properties, and it is considered to be one of the most dangerous and unstable countries (Khan et al., 2010a, 2010b, 2012; Top 10 Most Dangerous Countries in the World, 2013). More specifically, Iraq is classified as a developing country under redeveloping stage among other countries in the world (Al-Hakim, 2012). Many crises, difficulties, and hard conditions have been encountered in Iraq, such as the economic sanction, the first and second Gulf wars, the occupation by US troops from 2003 to 2011 and currently, conflicts, and domestic violence situations (Al-Hakim, 2012). These conditions have considerably contributed to public emergencies, violence, an unstable environment, and the collapse of the infrastructures in various sectors, such as the oil, electricity, education, and public services sectors (Al-Hakim, 2012). In addition, Dr. Abdulkerim Ali Yaseen Alsamarrai, the Minister of Science and Technology in Iraq, mentioned that Iraq has been facing several problems in eG projects. One major reason behind those problems is the lack of coordination between ministries (Al-Salam, 2011). Moreover, the National Strategy and Action Plan for eG in Iraq 2012-2015 recommended increasing the awareness of the benefits of $\mathrm{eG}$, calling for a suitable telecommunication infrastructure, and strengthening coordination and networking in all parts of Iraq.

Furthermore, many applications in Iraq that are related to information technology (IT) have been enumerated, citing e-business, e-education, and e-employment as examples of eG services. E-health application in Iraq is said to be still at the planning stage presently, and also experiences not enough researches and studies as far as the field of health discipline is concerned. In the light of this, the Ministry of Health and Human's Organizations is working together to come with a strategic plan to improve the situation (UN and ESCWA, 2007). 


\section{Technology acceptance and usage theories}

Generally, many studies in the literature section have specified different variables which can impact the behaviour and technology adoption among different nations (Helena and Maria, 2015; Raffaele et al., 2017). Moreover, based on the technology acceptance literature, several theories have been used to investigate IT usage and CUI issues, including use of eG services, include the theory of reasoned action (TRA), the theory of planned behaviour (TPB), the motivational model (MM), the model of PC utilisation (MPCU), the innovation diffusion theory (IDT), the technology acceptance model and the technology acceptance model two (TAM/TAM2), the combined technology acceptance theory of planned behaviour (CTAM/TPB), and the social cognitive theory (SCT) (Ovčjak et al., 2015).

Venkatesh et al. (2003) carried out a study to compare the similarities and differences among prior theories and models of user acceptance to formulate the unified theory of acceptance and use technology (UTAUT). This comparison included the technology acceptance model (Hong et al., 2006 Davis and Bagozzi, 1989), the TPB (Ajzen, 1991), the TRA (Fishbein and Ajzen, 1975; Abu-Auf et al., 2016), the CTAM/TPB (Taylor and Todd, 1995), the MPCU (Thompson et al., 1991), the IDT (Rogers, 2003), the SCT (Compeau and Higgins, 1995), and the MM (Davis et al., 1992). Their previous research work resulted in the introduction of the UTAUT model, which was created to overcome the difficulties initially faced by IT researchers in developing their studies' frameworks to better understand the usage of technology among users (Venkatesh et al., 2003).

Among all the technology acceptance theories, UTAUT is still the most comprehensive (Venkatesh et al., 2012). UTAUT is an empirical and experimental support that shows that IT (new innovation) usage, such as usage of eG, can be explored by UTAUT, which was developed in the USA (Venkatesh et al., 2003, 2011, 2012). Since the model covers both organisational and individual factors, it becomes appropriate and comprehensive to understand users' adoption of eG services (Venkatesh et al., 2011; Wang and Shih, 2009).

In more details, the (UTAUT) has four constructs to predict users' behavioural intentions and UB, namely:

a performance expectancy (PE)

b effort expectancy (EE)

c social influence (SI)

d facilitating conditions (FC) (Venkatesh et al., 2003).

The relationships between these constructs, behaviour intention and UB, are moderated by four key factors, i.e., age, gender, voluntariness, and experience (Venkatesh et al., 2003). As a theoretical foundation, the current study employed the UTAUT model as the core theory to explain the eG services usage and continued usage behaviours (CUBs). Thereupon, the current study fulfilled literature gape regarding to conflict environment in Iraq as a most dangerous country in the world (Top 10 Most Dangerous Countries in the World, 2013). 


\section{Hypothesis development}

\subsection{Electronic-services awareness and effort and PE}

The awareness of the citizen's about the availability and how to use the eG services is crucial (Jaeger and Thompson, 2003). That is why it was argued by Graafland-Essers and Ettedgui (2003) that the familiarity with eG services was highly correlated with attitude towards eG service use, and most of the citizen's were not always aware of the types of government services available online in different countries around the world. In addition, citizen's awareness of the existence of e-services online in an eG portal is a high priority since it could enhance the perceived effort and performance expectation of the eG services (Graafland-Essers and Ettedgui, 2003; Jaeger and Thompson, 2003; Khan et al., 2010a, 2010b, 2012; Meer and Winden, 2003).

In the Middle Eastern countries, where a study was conducted in Bahrain, the finding of the study confirms that there is a high positive correlation between awareness of eG services and the eG usage rate (Khan et al., 2010a, 2010b, 2012). It could, therefore, be reasonably argued that citizen awareness of the available eG services is likely to encourage eG usage among the citizen's, as eG services are expected to be technically easy to use and save time and effort compared with the traditional methods.

Carter and Bishath (2008) noted that increasing the awareness about the eG portal will increase their usage. Also, the government has a responsibility to promote awareness and encourage citizen's to use the eG services on the government portal. Studies noted that the government had a responsibility to publish the information about the availability of eG services and the launching of the eG portal to the public through various media and information channels, such as training programs to educate the citizen's on how to benefit from IT tools such as eG and others (Jaeger and Thompson, 2003). Thus the following hypotheses are proposed to be empirically tested.

H1 There is a significant effect of eG service awareness on efforts expectancy of eG services.

H2 There is a significant effect of eG service awareness on PE of eG services.

\subsection{EE and $U B$}

EE refers to perceived easiness of the system usage. The hypothesis of this study links an individual's EE and the UB of eG services. Additionally, it was argued by Marchewka et al. (2007) that EE is a significant determinant of the user's acceptance of IT. According to Kijsanayotin et al. (2009), this concept is similar in meaning to the perceived ease of use in the TAM and the IDT models and the complexity of the technology construct in the MPCU model. However, EE can be seen from two angles: perceived ease of use (TAM/TAM2) and ease of use (IDT). In Iraq, due to conflicts and the unstable environment (e.g., lack of electricity, internet connectivity, and mobile networks), all these factors negatively affect perceived ease of use and actual ease of use of eG services.

Many scholars (e.g., Abdul-Rahman et al., 2011; Al-Shafi and Weerakkody, 2009, 2010; Al-Sobhi et al., 2011; Alsyouf, 2018; Carlsson and Carlsson, 2006; Chou et al., 2018; Foon and Fah, 2011; Venkatesh et al., 2003, 2011; Weerakkody et al., 2013) 
confirmed the significant effect of EE on intention to use e services. In contrast, Adulwahab and Dahalin (2011) and $\mathrm{Wu}$ and Tao (2007) argue that EE does not have a significant impact of eG behavioural intention. However, there are very limited studies in Iraq that examined an eG setting and included $\mathrm{EE}$ as an antecedent of UB. The conceptual positive relationship between EE and BI was examined as shown in previous studies. In this study, EE is measured with the perceptions of employees towards eG services UB. Therefore, the researcher proposes the following hypothesis

H3 Effort expectancy has a positive influence on eG services UB.

\subsection{PE and $U B$}

PE refers to a person's beliefs that using a particular system will enhance his/her work performance (Venkatesh et al., 2003). Additionally, the user can get a benefit, where he/she does not have to go to a government office and request information or services in a conflict-laden environment and may save his or her life, particularly in unstable circumstances (violent environment). By means of electronic services, the quality of government services is improved, as it provides citizen's with equal benefits to carry out their businesses with the government (AlAwadhi and Morris, 2008; Al-Shafi and Weerakkody, 2009). According to past research, PE was confirmed to be a significant determinant of the intention to use IT systems (Chou et al., 2018; Cooper and Zmud, 1990; Davis and Bagozzi, 1989; Taylor and Todd, 1995; Venkatesh and Davis, 2000; Venkatesh et al., 2003). It is, therefore, appropriate to examine the following hypothesis:

H4 PE has an influence on eG services UB.

\subsection{FCs and $U B$}

FCs as a construct is defined to be the extent to which one believes that the infrastructure either organisational or technical is set up to support the implemented IT system (Venkatesh et al., 2003). In general, FCs are measured by the perception of being able to access required resources as well as to obtain the knowledge and necessary support needed to use eG services. FCs in the UTAUT are comprised of perceived behavioural control, FCs, and compatibility from the TPB, TAM, MPCU, and IDT models (Ajzen, 1991; Taylor and Todd, 1995; Venkatesh et al., 2003). The effect of FCs on IT system's users has been confirmed by many researchers in the field of technology studies (e.g., Al-Shafi and Weerakkody, 2010; Al-Sobhi et al., 2011; Adulwahab and Dahalin, 2011; Alsyouf and Ishak, 2018; Foon and Fah, 2011; Maldonado et al., 2011; Wu and Tao, 2007; Venkatesh et al., 2003). In line with the theory and previous arguments, the researcher proposes the following hypothesis for empirical testing:

H5 FCs have a significant influence on eG UB.

\subsection{SI and $U B$}

SI is defined in UTAUT as the extent of pressure exercised on the individual by his social circles of friends and family members to encourage him/her to use an IT system (Venkatesh et al., 2003). SI has been examined as a powerful factor in predicting technology usage behavioural intention (Venkatesh and Davis, 2000). According to the 
theory of the reasoned action, people's behaviour is affected by the way in which they believe others are important to them and how they think that a certain behaviour should or should not be followed. Additionally, Chou et al. (2018) and Maldonado et al. (2011) found that SI has a positive influence on behavioural intention. Based on the above, it is reasonable to test the following hypothesis:

H6 SI has an effect on the citizen's eG services UB.

\subsection{UB and $C U I$}

Behavioural psychology as a field of knowledge has helped researchers to extract various theories to explain the reasons behind the individual adoption of IT system. As argued by Venkatesh et al. (2003), the empirical studies informed that theories used to explain IT system UB account for about $50 \%$ of the variance of individual's use or intention towards the usage of IT. They have also tested 32 of the constructs taken from eight of the theoretical models in order to identify the most influential construct to explain the use of IT (Venkatesh et al., 2003). It was also confirmed by UTAUT theory and other recent studies (Alshehri et al., 2012; Reyes-Mercado, 2018) that the intention to use IT system is a major direct determinant of system use (Wu and Tao, 2007).

In light of the empirically supported impact of continued usage upon IT success, determining the main factors affecting post-adoption behaviour of the user (continuing or discontinuing IT usage) becomes significant and critical (Hong et al., 2006; Shaikh and Karjaluoto, 2015). The majority of previous IT adoption research has failed to examine the difference in user perceptions between the initial adoption and continued use (e.g., Bhattacherjee, 2001; Hong et al., 2006; Karahanna et al., 1999). An information system generally reflects that its success hinges upon continued use as opposed to first-time use (Bhattacherjee, 2001; Limayem et al., 2003; Wangpipatwong et al., 2008). Therefore, it is very important to measure the effect of current eG-related behaviour on future behaviour through examining the following hypothesis:

H7 A citizen's UB of eG services has a positive, significant influence on CUI of eG services.

\subsection{The intervening role of $U B$}

Mediating variables have been playing a key role in both psychological theory and research (MacKinnon and Fairchild, 2010). This type of variables enables the transmission of the antecedent variable's effect onto the dependent variable, hence providing a clarification of the variables' relationships (Kenny and Little, 2011; MacKinnon and Fairchild, 2010). Several methods have used the assessment of mediation in various research in past years (MacKinnon and Fairchild, 2010). A mediation analysis provides the identification of basic processes that underlie human behaviour and that are significant throughout behaviours and contexts (MacKinnon and Fairchild, 2010).

Following the identification of an actual mediating process, more efficient and effective interventions can be created, as a focus can be placed on the variables in the process of mediation (MacKinnon and Fairchild, 2010). Various methods of mediation-analysis with the inclusion of statistical and experimental methods have been 
utilised in the field of psychology. In addition, mediation analysis has become a significant area of substantive and methodological studies (MacKinnon and Fairchild, 2010).

Figure 1 The research framework based on the literature review and the hypothesis development, the hypothesised model is depicted in Figure 1

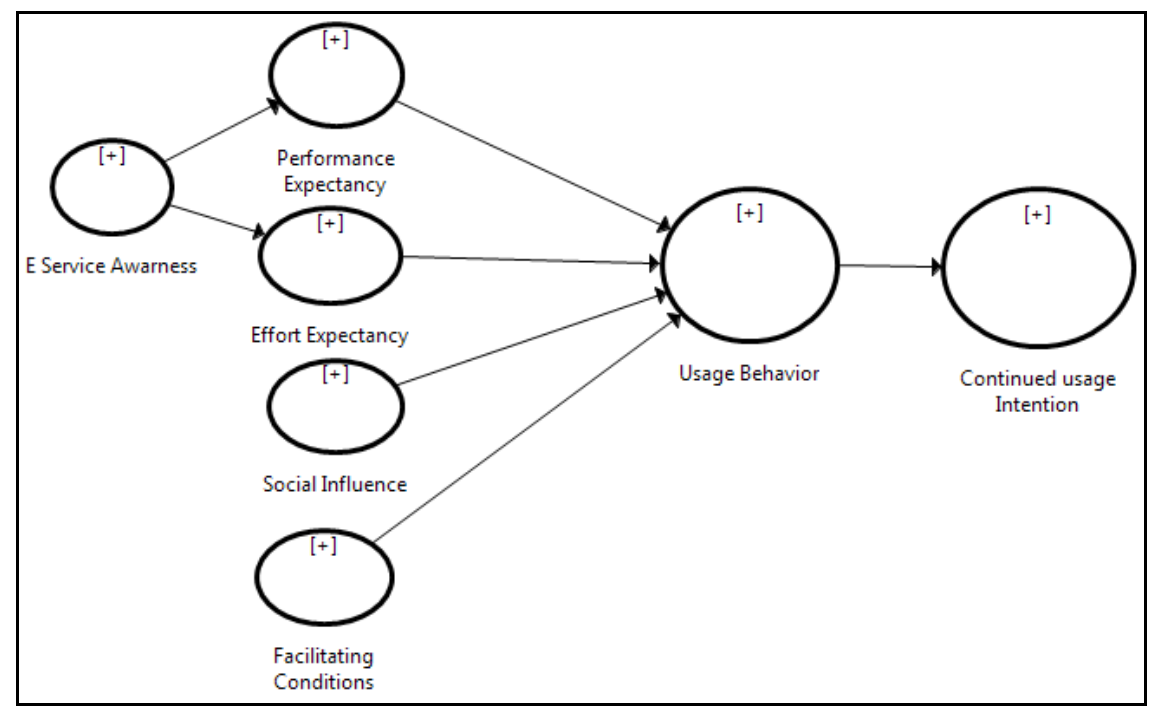

Note: This framework was built in the light of the UTAUT theory.

The extant and potential mediation analysis developments assist in obtaining authentic answers to the question as to the manner and the reason behind the relationship between two variables (MacKinnon and Fairchild, 2010). Moreover, in public emergencies and security instability, people would be more likely to use the eG service system if they have good experiences and realised the benefits from using such systems. This justifies the choice of eG UB as a mediator between UTAUT antecedents such as EE, FC, PE, and SI and the future usage intention of eG services. To explain the mediating effect, the following hypotheses were proposed:

H8 The citizen UB mediates the effect of EE on CUI of eG services.

H9 The citizen UB mediates the effect of PE on CUI of eG services.

H10 The citizen UB mediates the effect of FCs on CUI of eG services.

H11 The citizen UB mediates the effect of SI on CUI of eG services.

\section{Research design}

\subsection{Research participants}

This study was applied in the eG services context, which involves the employees of public universities, who are users of eG services. Quantitative approach is the best (Yusr et al., 2017) to be implementing in the current research, because it assets the researcher to 
survey a huge sample of the opinions of the respondent about the specific issue clearly (Abu-Auf et al., 2016). The study has targeted the university employees for different reasons. First, they are more likely to use the Iraqi eG portal to access their salaries and pay their government various fees. Second, these employees are provided with internet access and possess the basic required ICT knowledge. Third, the list of the employees in all the universities was easily made available by the Ministry of Higher Education - Department of Statistics and Informatics. A sample of 700 employees was identified to whom the questionnaires were distributed. Out of that, only 436 returned ones were complete and used for the study.

\subsection{Research instruments}

The questionnaire was comprised of two parts. The first part was dedicated to gathering information about the respondents according to some demographic variables such as gender, age and education. The second part consisted of questions measuring the constructs of the study. Table 1 summarises the operational definitions of the studied.

Table 1 Operational definition of constructs

\begin{tabular}{lcc}
\hline Variable & Items & Source \\
\hline Social influence (SI) & 5 & Venkatesh et al. (2003) \\
Electronic service awareness (ESA) & 5 & Khan et al. (2010a, 2010b, 2012) \\
Performance expectancy (PE) & 5 & Venkatesh et al. (2003) \\
Effort expectancy (EE) & 5 & Venkatesh et al. (2003) \\
Facilitating condition (FC) & 5 & AlAwadhi and Morris (2008) \\
Use behaviour of eG services (UB) & 4 & Raman et al. (2008) \\
Continued usage intention (CUI) & 4 & Bhattacherjee (2001) \\
\hline
\end{tabular}

\section{Statistical analysis and results}

\subsection{Sampling profile}

As Table 2 illustrates, the respondents were distributed according to gender, age, marital status, job position and educational level. With regards to the gender, the sample was equally distributed between males and females. In regards to the age, respondents aged less than 35 years represent $45 \%$ of the total respondents, ages 36 to 45 made up only $35.8 \%$, ages 46 to 55 made up $15.4 \%$, and those who were 56 or above made up only $3.7 \%$. The majority of the respondents (297) were married, which made up $68.1 \%$, while the single respondents represent $26.1 \%$. Additionally, the majority of the respondents, representing $63.8 \%$, have administrative roles in managerial positions. Moreover, the results indicate that $172(39.4 \%)$ of the respondents had Bachelor degrees, while 104 (23.9\%) of them had Master degrees and $17.0 \%$ had PhD degrees. The results also showed that the targeted sample has experience in using the internet where more that $80 \%$ has experience exceeding one year. The results pertaining to the monthly income revealed that more than half of the sample surveyed has a monthly income of more than 600 USD which is considered high in Iraq due to the economic situation. 
Table 2 Sample profile

\begin{tabular}{|c|c|c|c|}
\hline Demographic variable & Category & Frequency $(n=436)$ & Percent $\%$ \\
\hline \multirow[t]{2}{*}{ Gender } & Male & 222 & 50.9 \\
\hline & Female & 214 & 49.1 \\
\hline \multirow[t]{5}{*}{ Age } & $\leq 22$ & 15 & 3.4 \\
\hline & $23-35$ & 182 & 41.7 \\
\hline & $36-45$ & 156 & 35.8 \\
\hline & $46-55$ & 67 & 15.4 \\
\hline & 56 or above & 16 & 3.7 \\
\hline \multirow[t]{4}{*}{ Monthly income } & $<\$ 210$ & 17 & 3.9 \\
\hline & Between $\$ 210$ and $\$ 420$ & 61 & 14 \\
\hline & Between $\$ 420$ and $\$ 630$ & 130 & 29.8 \\
\hline & $>630 \$$ & 228 & 52.3 \\
\hline \multirow[t]{4}{*}{ Internet experience } & $<1$ year & 94 & 21.6 \\
\hline & Between 1 and 3 years & 148 & 33.9 \\
\hline & Between 3 and 5 years & 87 & 20 \\
\hline & $>5$ years & 107 & 24.5 \\
\hline \multirow[t]{4}{*}{ Marital status } & Single & 114 & 26.1 \\
\hline & Married & 297 & 68.1 \\
\hline & Divorced & 15 & 3.4 \\
\hline & Widowed & 10 & 2.3 \\
\hline \multirow[t]{5}{*}{ Job position } & Lecturer & 158 & 36.2 \\
\hline & Manager & 56 & 12.8 \\
\hline & Officer & 178 & 40.8 \\
\hline & Clerks & 23 & 5.3 \\
\hline & Others & 21 & 4.8 \\
\hline \multirow[t]{6}{*}{ Education level } & $\mathrm{PhD}$ & 74 & 17 \\
\hline & Master & 104 & 23.9 \\
\hline & Bachelor & 172 & 39.4 \\
\hline & Diploma & 58 & 13.3 \\
\hline & Secondary school & 21 & 4.8 \\
\hline & Other & 8 & 3.4 \\
\hline
\end{tabular}

\section{Analysis and results}

To ensure valid and reliable results, this study followed the bulk of SEM literature by confirming the validity and reliability of the constructs used before proceeding to test the hypotheses (Hair et al., 2010). The structural equation modelling (SEM-PLS) approach was employed using SmartPLS version 3. 


\section{Measurement reliability and validity}

\subsection{Convergence validity analysis}

The convergent validity of the model refers to the level to which a set of variables converge in their measurement of a specific concept (Hair et al., 2010). In order to confirm the convergent validity, several criteria are tested, which include factor loadings, composite reliability (CR), and average variance extracted (AVE) (Griffin and Halpin, 2005) as recommended by Hair et al. (2010). In this process, the loadings of the items were examined to reveal that all of them have loadings over 0.50 , which is an acceptable level of loading as suggested in the literature concerning multivariate analysis (Hair et al., 2010).

The CR is another way to confirm the convergence validity, and it shows the level to which a set of items consistently measure the latent construct (Hair et al., 2010). The CR of the constructs was examined, and their values are listed in Table 3. It is notable that the values of $\mathrm{CR}$ ranged from 0.863 to 0.936 , which is over the recommended value of 0.70 (Fornell and Larcker, 1981; Hair et al., 2010).

Table 3 Convergence validity analysis

\begin{tabular}{|c|c|c|c|c|c|c|c|c|c|c|}
\hline \multirow{2}{*}{ Items } & \multirow{2}{*}{$C U I$} & \multirow{2}{*}{$E E$} & \multirow{2}{*}{$E S A$} & \multirow{2}{*}{$F C$} & \multirow{2}{*}{$P E$} & \multirow{2}{*}{$S I$} & \multirow{2}{*}{$U B$} & \multirow{2}{*}{$\begin{array}{l}\text { Cronbach's } \\
\text { alpha }\end{array}$} & \multicolumn{2}{|c|}{ Convergent validity } \\
\hline & & & & & & & & & $C R$ & $A V E$ \\
\hline CUI1 & 0.875 & & & & & & & 0.911 & 0.937 & 0.789 \\
\hline CUI2 & 0.892 & & & & & & & & & \\
\hline CUI3 & 0.914 & & & & & & & & & \\
\hline CUI4 & 0.870 & & & & & & & & & \\
\hline EE1 & & 0.786 & & & & & & 0.878 & 0.911 & 0.672 \\
\hline EE2 & & 0.843 & & & & & & & & \\
\hline EE3 & & 0.853 & & & & & & & & \\
\hline EE4 & & 0.798 & & & & & & & & \\
\hline EE5 & & 0.816 & & & & & & & & \\
\hline ESA1 & & & 0.833 & & & & & 0.871 & 0.907 & 0.661 \\
\hline ESA2 & & & 0.826 & & & & & & & \\
\hline ESA3 & & & 0.907 & & & & & & & \\
\hline ESA4 & & & 0.743 & & & & & & & \\
\hline ESA5 & & & 0.745 & & & & & & & \\
\hline $\mathrm{FC} 1$ & & & & 0.790 & & & & 0.856 & 0.902 & 0.697 \\
\hline $\mathrm{FC} 2$ & & & & 0.835 & & & & & & \\
\hline $\mathrm{FC} 4$ & & & & 0.860 & & & & & & \\
\hline FC5 & & & & 0.853 & & & & & & \\
\hline
\end{tabular}

Notes: CUI - continued usage intention; CR - composite reliability; EE - effort expectancy; AVE - average variance extracted; ESA - electronic service awareness; FC - facilitating conditions; $\mathrm{PE}$ - performance expectancy. 
Table 3 Convergence validity analysis (continued)

\begin{tabular}{|c|c|c|c|c|c|c|c|c|c|c|}
\hline \multirow{2}{*}{ Items } & \multirow{2}{*}{$C U I$} & \multirow{2}{*}{$E E$} & \multirow{2}{*}{ ESA } & \multirow{2}{*}{$F C$} & \multirow{2}{*}{$P E$} & \multirow{2}{*}{$S I$} & \multirow{2}{*}{$U B$} & \multirow{2}{*}{$\begin{array}{l}\text { Cronbach's } \\
\text { alpha }\end{array}$} & \multicolumn{2}{|c|}{ Convergent validity } \\
\hline & & & & & & & & & $C R$ & $A V E$ \\
\hline PE1 & & & & & 0.861 & & & 0.914 & 0.936 & 0.744 \\
\hline PE2 & & & & & 0.915 & & & & & \\
\hline PE3 & & & & & 0.880 & & & & & \\
\hline PE4 & & & & & 0.811 & & & & & \\
\hline PE6 & & & & & 0.843 & & & & & \\
\hline SI1 & & & & & & 0.683 & & 0.810 & 0.864 & 0.560 \\
\hline $\mathrm{SI} 2$ & & & & & & 0.808 & & & & \\
\hline SI3 & & & & & & 0.709 & & & & \\
\hline SI4 & & & & & & 0.781 & & & & \\
\hline SI5 & & & & & & 0.755 & & & & \\
\hline UB1 & & & & & & & 0.875 & 0.894 & 0.927 & 0.760 \\
\hline UB2 & & & & & & & 0.923 & & & \\
\hline UB3 & & & & & & & 0.866 & & & \\
\hline UB4 & & & & & & & 0.821 & & & \\
\hline
\end{tabular}

Notes: CUI - continued usage intention; CR - composite reliability; EE - effort expectancy; AVE - average variance extracted; ESA - electronic service awareness; FC - facilitating conditions; PE - performance expectancy.

The convergence validity of the outer model was further confirmed by examining the AVE, which reflects the AVE from the set of items relative to the variance shared with the measurement errors. In cases where the AVE values are at least 0.50, they show that the set of items are characterised by adequate convergence in measuring the construct (Bagozzi and Yi, 1988; Barclay et al., 1995). All AVE values ranged from 0.559 to 0.789 , which reveals a suitable level of the measures' construct validity (Barclay et al., 1995).

\subsection{Discriminant validity analysis}

As a definition, discriminant validity refers to the degree to which the measures of different concepts are distinct and their items can differentiate them from other constructs in the model. To examine the discriminant validity, two methods were examined. First, the cross loadings of the items on their respective constructs were examined. According the discriminant validity, the model will be said to have confirmed the discriminant validity if all the items meant to measure a construct are loading highly on their respective construct compared to other constructs in the model. As illustrated in Table 4, the results indicated that items have higher loading on their respective constructs than their loadings on other constructs in the model. Hence, the discriminant validity is supported. 
Table 4 Cross-loading analysis

\begin{tabular}{|c|c|c|c|c|c|c|c|}
\hline Items & $C U I$ & $E E$ & $E S A$ & $F C$ & $P E$ & $S I$ & $U B$ \\
\hline CUI1 & 0.875 & 0.541 & 0.290 & 0.628 & 0.490 & 0.315 & 0.683 \\
\hline CUI2 & 0.892 & 0.582 & 0.273 & 0.599 & 0.519 & 0.365 & 0.716 \\
\hline CUI3 & 0.914 & 0.529 & 0.314 & 0.618 & 0.510 & 0.327 & 0.701 \\
\hline CUI4 & 0.870 & 0.557 & 0.355 & 0.626 & 0.559 & 0.348 & 0.731 \\
\hline EE1 & 0.462 & 0.786 & 0.427 & 0.510 & 0.469 & 0.412 & 0.495 \\
\hline EE2 & 0.455 & 0.843 & 0.391 & 0.535 & 0.452 & 0.423 & 0.518 \\
\hline EE3 & 0.438 & 0.853 & 0.391 & 0.539 & 0.471 & 0.407 & 0.520 \\
\hline EE4 & 0.606 & 0.798 & 0.291 & 0.598 & 0.574 & 0.419 & 0.663 \\
\hline EE5 & 0.572 & 0.816 & 0.361 & 0.707 & 0.474 & 0.386 & 0.586 \\
\hline ESA1 & 0.279 & 0.387 & 0.833 & 0.446 & 0.405 & 0.462 & 0.243 \\
\hline ESA2 & 0.384 & 0.399 & 0.826 & 0.489 & 0.488 & 0.504 & 0.343 \\
\hline ESA3 & 0.297 & 0.430 & 0.907 & 0.458 & 0.467 & 0.485 & 0.288 \\
\hline ESA4 & 0.203 & 0.295 & 0.743 & 0.242 & 0.345 & 0.327 & 0.212 \\
\hline ESA5 & 0.220 & 0.307 & 0.745 & 0.285 & 0.378 & 0.372 & 0.192 \\
\hline $\mathrm{FC} 1$ & 0.522 & 0.556 & 0.443 & 0.790 & 0.419 & 0.424 & 0.491 \\
\hline $\mathrm{FC} 2$ & 0.488 & 0.612 & 0.476 & 0.835 & 0.377 & 0.433 & 0.470 \\
\hline FC4 & 0.658 & 0.615 & 0.352 & 0.860 & 0.537 & 0.395 & 0.653 \\
\hline FC5 & 0.625 & 0.582 & 0.378 & 0.853 & 0.430 & 0.381 & 0.574 \\
\hline PE1 & 0.548 & 0.518 & 0.474 & 0.495 & 0.861 & 0.493 & 0.588 \\
\hline PE2 & 0.513 & 0.525 & 0.452 & 0.436 & 0.915 & 0.469 & 0.589 \\
\hline PE3 & 0.553 & 0.544 & 0.430 & 0.473 & 0.880 & 0.483 & 0.616 \\
\hline PE4 & 0.413 & 0.483 & 0.477 & 0.421 & 0.811 & 0.427 & 0.481 \\
\hline PE6 & 0.492 & 0.507 & 0.399 & 0.483 & 0.843 & 0.428 & 0.542 \\
\hline SI1 & 0.167 & 0.353 & 0.371 & 0.332 & 0.266 & 0.683 & 0.228 \\
\hline SI2 & 0.303 & 0.385 & 0.426 & 0.447 & 0.385 & 0.808 & 0.320 \\
\hline SI3 & 0.198 & 0.333 & 0.457 & 0.260 & 0.258 & 0.709 & 0.182 \\
\hline SI4 & 0.416 & 0.444 & 0.355 & 0.409 & 0.586 & 0.781 & 0.408 \\
\hline SI5 & 0.239 & 0.319 & 0.460 & 0.305 & 0.364 & 0.755 & 0.244 \\
\hline UB1 & 0.762 & 0.589 & 0.262 & 0.623 & 0.583 & 0.350 & 0.875 \\
\hline UB2 & 0.717 & 0.625 & 0.306 & 0.605 & 0.605 & 0.376 & 0.923 \\
\hline UB3 & 0.622 & 0.646 & 0.302 & 0.578 & 0.582 & 0.336 & 0.866 \\
\hline UB4 & 0.674 & 0.518 & 0.248 & 0.506 & 0.509 & 0.314 & 0.821 \\
\hline
\end{tabular}

Another method to confirm the discriminant validity is the Forner-Larcker criterion (1981). Based on this criterion, , discriminant validity can be examined by comparing the correlations between constructs (non diagonal elements in the correlation matrix) and the square root of the AVE (Griffin and Halpin, 2005) for a construct, diagonal elements (Fornell and Larcker, 1981). The model is said to have the discriminant validity for all the constructs if all the diagonal elements are higher than the non-diagonal elements in the row and columns in which they lie. Table 4 and Table 5 indicated that all the items 
designed to measure a specific construct could differentiate that construct from other constructs in the model, and this confirms the discriminant validity of the measurements used.

Table 5 Discriminant analysis matrix (Forner-Larcker criterion)

\begin{tabular}{|c|c|c|c|c|c|c|c|c|c|c|}
\hline \multicolumn{11}{|c|}{ Construct } \\
\hline \multirow[t]{6}{*}{1} & \multirow{2}{*}{\multicolumn{3}{|c|}{$\begin{array}{l}\text { Continued usage intention } \\
\text { (National Strategy and Action } \\
\text { Plan E-governance in Iraqi, } \\
\text { 2012-2015) electronic service } \\
\text { awareness }\end{array}$}} & 0.888 & & & & & & \\
\hline & & & & 0.347 & 0.813 & & & & & \\
\hline & \multicolumn{3}{|c|}{$\begin{array}{l}\text { (Oliveira et al., 2014) effort } \\
\text { expectancy }\end{array}$} & 0.622 & 0.453 & 0.820 & & & & \\
\hline & \multicolumn{3}{|c|}{ Facilitating conditions } & 0.695 & 0.485 & 0.708 & 0.835 & & & \\
\hline & \multicolumn{3}{|c|}{$\begin{array}{l}\text { (National Strategy and Action } \\
\text { Plan E-governance in Iraqi, } \\
\text { 2012-2015) performance } \\
\text { expectancy }\end{array}$} & 0.586 & 0.518 & 0.598 & 0.535 & 0.863 & & \\
\hline & \multicolumn{3}{|c|}{$\begin{array}{l}\text { (Oliveira et al., 2014) social } \\
\text { influence }\end{array}$} & 0.382 & 0.536 & 0.500 & 0.485 & 0.534 & 0.749 & \\
\hline 7 & \multicolumn{3}{|c|}{ Usage behaviour } & 0.797 & 0.320 & 0.683 & 0.665 & 0.655 & 0.396 & 0.872 \\
\hline \multicolumn{11}{|c|}{ Table 6} \\
\hline \multicolumn{2}{|c|}{ Construct } & $C U I$ & $E S A$ & $E E$ & \multicolumn{2}{|c|}{$F C$} & $P E$ & \multicolumn{2}{|c|}{ SI } & $U B$ \\
\hline \multicolumn{11}{|c|}{ CUI } \\
\hline \multicolumn{2}{|c|}{ ESA } & 0.382 & & & & & & & & \\
\hline \multicolumn{2}{|c|}{$\mathrm{EE}$} & 0.691 & 0.514 & & & & & & & \\
\hline \multicolumn{2}{|c|}{$\mathrm{FC}$} & 0.777 & 0.557 & 0.813 & & & & & & \\
\hline \multicolumn{2}{|c|}{$\mathrm{PE}$} & 0.640 & 0.575 & 0.665 & \multicolumn{2}{|c|}{0.596} & & & & \\
\hline \multicolumn{2}{|c|}{ SI } & 0.408 & 0.645 & 0.577 & \multicolumn{2}{|c|}{0.563} & 0.573 & & & \\
\hline \multicolumn{2}{|c|}{ UB } & 0.882 & 0.357 & 0.766 & \multicolumn{2}{|c|}{0.746} & 0.722 & \multicolumn{2}{|c|}{0.430} & \\
\hline
\end{tabular}

To handle the potential weaknesses of establishing the discriminant validity based on cross loading and the Fornell-Larcker criterion, as they are described as not effective under certain circumstances (Henseler et al., 2014), the hetrotrait-monotrait (HTMT) ratio method was employed (Henseler et al., 2014). To establish discriminant validity, we compute the HTMT criteria for each pair of constructs on the basis of the item correlations. The HTMT is the ratio of the average of the heterotrait-heteromethod correlations (i.e., the correlations of indicators across constructs measuring different phenomena) and the average of the monotrait-heteromethod correlations (i.e., the correlations of indicators within the same construct). Since there are two monotrait-heteromethod sub-matrices, we take the geometric mean of their average correlations (Henseler et al., 2014). According to Kline (2011) and Teo et al. (2009), HTMT values less than 0.90 or 0.95 indicate an adequate level of discriminant validity of the measures used. The results in Table 6 indicate that our measures have an adequate discriminant validity level since all the values are less than 0.90 (Kline, 2011). 


\subsection{Model prediction quality}

The goodness of the model fit in PLS is still under research and the indicators provided to assess the model goodness of fit are still exposed to empirical investigation (Hair et al., 2017). In general, the model has shown a value of standardised root mean square residual (SRMR), of 0.075 which is less than the suggested value of 0.08 as suggested by $\mathrm{Hu}$ and Bentler (1999). In addition to that, the normed fit index (NFI) or the Bentler and Bonett index has the value of 0.91 which exceeds the value of 0.90 as suggested by $\mathrm{Hu}$ and Bentler (1998). These results, therefore, suggested that the model has an adequate goodness fit and hence could produce valid and reliable results.

In the multivariate analysis literature, the model quality can be assessed employing different criteria. In our studies, we first assess the value of the $\mathrm{R}^{2}$, which refers to the amount of variance in the criterion variable that is being explained jointly by the independent variables in the hypothesised model. As shown in Table 7, the model developed could explain $60 \%$ of the variance of the actual UB and $64 \%$ of the variance of the CUI. These values are deemed very substantial when compared to all the threshold values reported in the multivariate literature (Hair et al., 2010). The results also showed that the awareness of eG services could explain $20 \%$ of the variance of EE and $27 \%$ of the variance of PE. In addition to $\mathrm{R}^{2}$, the quality of the model could be assessed by examining cross-validated redundancy and communality of the UB and CUI. Table 7 showed that cross-validated redundancy values are found to be 0.603 and 0.635 more than zero, indicating an adequate predictive validity of the model, as suggested by Fornell and Cha (1994).

Table 7 Model quality indicators

\begin{tabular}{lcc}
\hline Endogenous construct & R squared & Cross-validated redundancy \\
\hline Actual usage & 0.603 & 0.455 \\
Continued usage intention & 0.635 & 0.5 \\
Effort expectancy & 0.203 & 0.137 \\
Performance expectancy & 0.266 & 0.198 \\
\hline
\end{tabular}

\subsection{Structural model results and hypothesis testing}

After the validity and reliability of the model were confirmed, the next step was to test the hypothesised model. In so doing, the SEM-PLS methodology was followed and the path modelling results were generated as depicted in Figure 2 and Table 6.

The results in Table 8 showed that the awareness of eG has positive, significant effects on both $\mathrm{EE}(\beta=0.453, t=10.278, p<0.001)$ and $\mathrm{PE}(\beta=0.518, t=13.527$, $p<0.001)$ supporting H1 and H2 hypotheses. Similarly, EE, PE and FCs have a positive, significant effect on UB at the 0.001 level of significance with indicators $(\beta=0.295$, $t=5.324, p<0.001),(\beta=0.365, t=7.514, p<0.001)$ and $(\beta=0.307, t=5.756$, $p<0.001)$, respectively. These results, therefore, support hypotheses H3, H4, and H5 as articulated in the study. Unexpectedly, SI was not a significant predictor of the UB.

The results also confirmed the strong effect of UB on the CUB of eG services at the 0.001 level of significance $(\beta=0.797, t=29.257, p<0.001)$.

Importantly, the results of the study as illustrated in Table 9 confirmed the mediating effect of UB between EE, FCs, and PE from one side and CUB from the other. The 
indirect effects were significant at the 0.001 level of significance $\left(a^{*} b=0.235, t=5.291\right.$, $p<0.001),\left(a^{*} b=0.245, t=5.367, p<0.001\right)$ and $\left(a^{*} b=0.291, t=7.527, p<0.001\right)$. It was also found that UB could transform $59 \%$ - as variance accounted for (VAF) $-34 \%$, and $49 \%$ of the effect of EE, FCs, and PE on eG CUB, respectively. Therefore, the results supported the hypotheses $\mathrm{H} 8, \mathrm{H} 9$, and $\mathrm{H} 10$ but did not supported $\mathrm{H} 11$.

Figure 2 The structural model

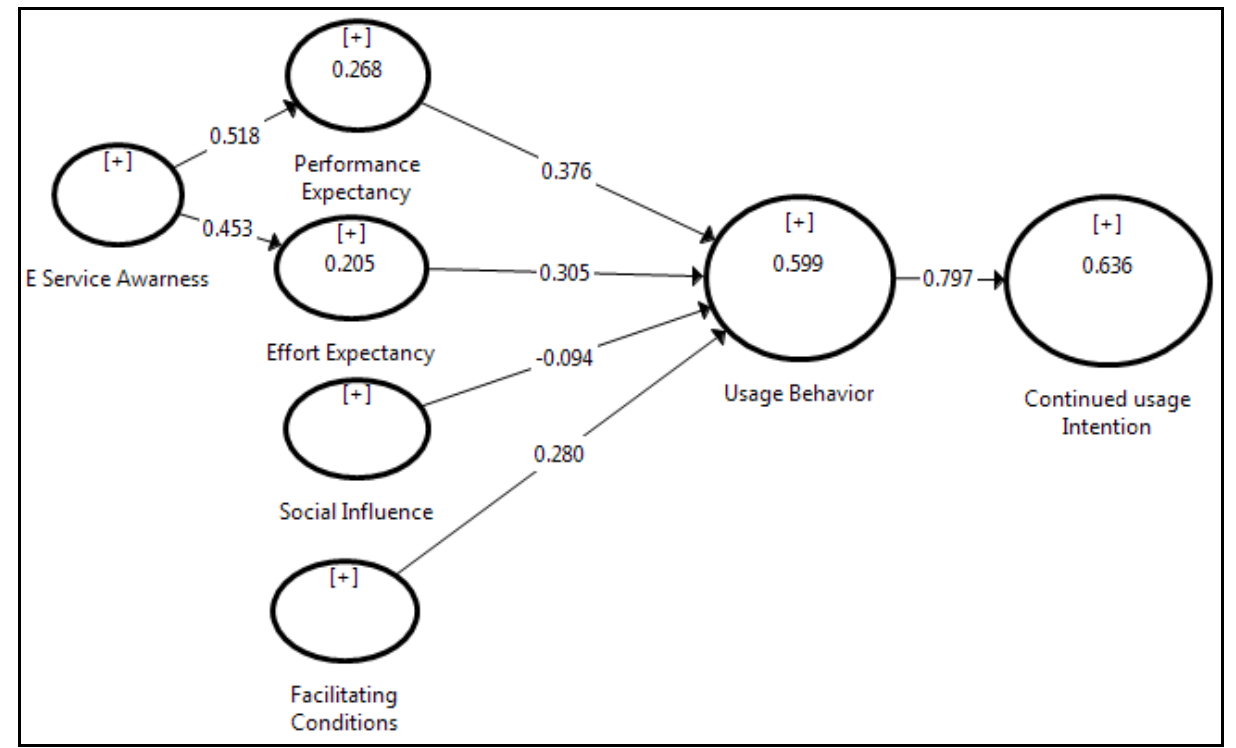

Table 8 Hypotheses testing analysis

\begin{tabular}{llccccc}
\hline $\begin{array}{l}\text { Hyp. } \\
\text { no. }\end{array}$ & \multicolumn{1}{c}{ Hypothesis statement } & $\begin{array}{c}\text { Path } \\
\text { coefficient }\end{array}$ & $\begin{array}{c}\text { Standard } \\
\text { error }\end{array}$ & $\begin{array}{c}T \\
\text { value }\end{array}$ & $\begin{array}{c}P \\
\text { value }\end{array}$ & Decision \\
\hline H1 & $\begin{array}{l}\text { Electronic service } \\
\text { awareness } \rightarrow \text { effort } \\
\text { expectancy }\end{array}$ & $0.453^{* * *}$ & 0.044 & 10.278 & 0.000 & Supported \\
H2 & $\begin{array}{l}\text { E-service } \\
\text { awareness } \rightarrow \text { performance } \\
\text { expectancy }\end{array}$ & $0.518^{* * *}$ & 0.038 & 13.527 & 0.000 & Supported \\
H3 & $\begin{array}{l}\text { Effort expectancy } \rightarrow \text { usage } \\
\text { behaviour }\end{array}$ & $0.295^{* * *}$ & 0.055 & 5.324 & 0.000 & Supported \\
H4 & $\begin{array}{l}\text { Facilitating conditions } \rightarrow \\
\text { usage behaviour }\end{array}$ & $0.307^{* * *}$ & 0.053 & 5.756 & 0.000 & Supported \\
H5 & $\begin{array}{l}\text { Performance expectancy } \rightarrow \\
\text { usage behaviour }\end{array}$ & $0.365^{* * *}$ & 0.049 & 7.514 & 0.000 & Supported \\
H6 & $\begin{array}{l}\text { Social influence } \rightarrow \text { usage } \\
\text { behaviour }\end{array}$ & -0.096 & 0.043 & 2.243 & 0.025 & Not \\
H7 & $\begin{array}{l}\text { Usage behaviour } \rightarrow \text { continued } \\
\text { usage intention }\end{array}$ & $0.797^{* * *}$ & 0.027 & 29.257 & 0.000 & Supported \\
\hline
\end{tabular}

Notes: $* * * p<0.001 ; * * p<0.01 ; * p<0.05$. 
Table 9 Direct and indirect effects results

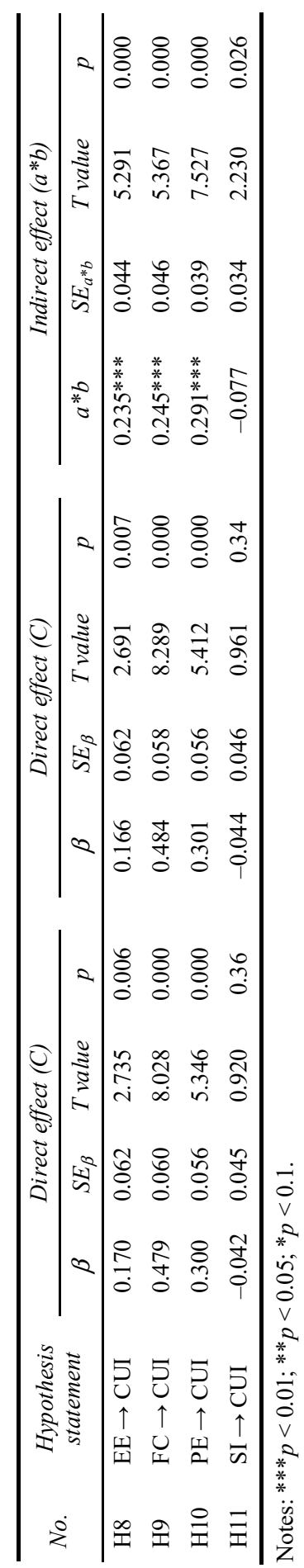




\subsection{Effect size analysis}

The effect of size estimates defines the practical significance of an effect and is independent of the size of sample. The measures of effect size are significant in the interpretation of results, as they can relay non-significant findings and improve the understanding of the practical use of statistically significant impacts (Fairchild and McQuillin, 2010).

Table 10 Effect size results

\begin{tabular}{lcccc}
\hline Effect & Effect size & SD & T value & P value \\
\hline Electronic service awareness $\rightarrow$ effort expectancy & 0.258 & 0.065 & 3.943 & 0.000 \\
Electronic service awareness $\rightarrow$ performance & 0.366 & 0.077 & 4.747 & 0.000 \\
expectancy & & & & \\
Effort expectancy $\rightarrow$ usage behaviour & 0.094 & 0.038 & 2.444 & 0.015 \\
Facilitating conditions $\rightarrow$ usage behaviour & 0.112 & 0.041 & 2.712 & 0.007 \\
Performance expectancy $\rightarrow$ usage behaviour & 0.189 & 0.055 & 3.417 & 0.001 \\
Social influence $\rightarrow$ usage behaviour & 0.015 & 0.014 & 1.075 & 0.283 \\
Usage behaviour $\rightarrow$ continued usage intention & 1.746 & 0.339 & 5.149 & 0.000 \\
\hline
\end{tabular}

As the results in Table 10 illustrate, all the variables have significant effects on their respective endogenous variables, except for SI, which demonstrated insignificant effect size, as it was found to not be a significant predictor of both usage and CUBs.

\section{Discussion}

This study aimed to validate the UTAUT model in an unstable security environment and extend the model to predict eG service usage continuity behaviour. In other words, this study addressed the applicability of the UTAUT, which was established in developed countries, to other non-Western cultures or developing countries. The major perception is that most technology adoption and acceptance theories are designed and produced in developed countries and are culturally biased in the context of those developed countries' social and cultural systems. This bias might arrest the applicability of these technologies theories when moving to other cultures and other environments. Conversely, IT advancements in the past few decades since internet technology and its benefits became available have made it basically impossible for governments globally to ignore these advantages or avoid internet technology.

One of the main aims of this study was to examine the effect of eG service awareness in shaping the average citizen's perception of how easy it is to use the services and how great their influence on our performance is. Several studies have revealed that awareness of the availability and the features of eG services are very important in enhancing and increasing the success of innovation. This study examined the effect of awareness on EE and $\mathrm{PE}$, and the results turned out to be positive and significant and support logical thinking. Hence, this result supports $\mathrm{H} 1$ and $\mathrm{H} 2$ as postulated in the study. The more citizen's know about the services' availability and usage, the more they will appreciate their value in making their lives easier. That is why, for any new information systems set, there should be intensive efforts made to raise the awareness of e-services for the users in 
order to educate them on how these systems could make our lives more sophisticated. Citizen's awareness of the availability of eG services is crucial, of a high priority and a fundamental factor for successful eG systems (Carter and Bishath, 2008; Khan et al., 2010a, 2010b, 2012).

In examining the hypothesis regarding the effect of $\mathrm{EE}$ on $\mathrm{eG}$ service $\mathrm{UB}$, the results indicate that EE has a significant and positive influence on UB, thus supporting H3. This finding is consistent with previous studies that have provided empirical evidence confirming the significant, positive effect of EE on UB (Wu and Tao, 2007). Previous literature confirms that $\mathrm{EE}$ is an important factor in the adoption of IT in different countries (Abdul-Rahman et al., 2011; AlAwadhi and Morris, 2008; Al-Shafi and Weerakkody, 2009, 2010; Al-Sobhi et al., 2011; Foon and Fah, 2011; Reyes-Mercado, 2018; Venkatesh et al., 2003, 2011). Importantly, there is a "need for skilled human resources for e-government success" [Khan et al., (2012), p.451].

Regarding the effect of $\mathrm{FC}$ on eG service usage behaviour (UB), the results show that FC has a significant and positive influence on UB. This finding, herefore, supports the hypothesised relationship in H4. This finding is in line with previous studies that have provided empirical evidence of the significant, positive effect of FC on UB (Adulwahab and Dahalin, 2011; AlAwadhi and Morris, 2008; Foon and Fah, 2011; Maldonado et al., 2011; Venkatesh et al., 2011; Wang and Shih, 2009; Wu and Tao, 2007).

In examining the hypotheses related to the relationship between PE and eG service $\mathrm{UB}$, the results showed that PE has a significant positive impact on UB at the 0.001 level of significance. This result, therefore, supports the hypothesised relationship postulated in H5 and is found to be along the same lines as previous literature (e.g., Al-Shafi and Weerakkody, 2010; Al-Sobhi et al., 2011; Venkatesh, et al., 2003, 2011, 2012; Wu and Tao, 2007; Yahya et al., 2011). These findings suggest that individual performances can be improved when the individual uses eG services. Thus, in order for eG services to be widely used and accepted by citizen's, eG services authorities should address citizen's usage behaviours and PE.

Unexpectedly, the effect of SI on eG service UB was not confirmed based on the results of the study. This finding did not support H6, which went against the findings of previous literature. Previous empirical studies recommended that SI should play a critical role with regards to the adoption or usage of new technology (Al-Shafi and Weerakkody, 2010; Foon and Fah, 2011; Maldonado et al., 2011; Yahya et al., 2011; Wu and Tao, 2007; Venkatesh et al., 2003, 2011; Wang and Shih, 2009). On the other hand, SI may be a necessary condition, but it is not sufficient to motivate users to adopt eG services in the midst of conflicts and risky environments. However, the results of the study regarding SI are similar to some studies such as those conducted on eG services in Saudi Arabia (Al-Sobhi et al., 2011; Alshehri et al., 2012) as well as in web-based learning area in Taiwan (Chiu and Wang, 2008). Thus, the implication of SI in Iraq does not have any effect on usage behaviour in the context of conflictual and violent environments. In electronic services in unstable security context, the user of eG services does not have any influence from their pair group on their usage of eG services. The finding further validates the non-significance of maintaining SI in assessing technology. Some other variables related to perceived safety and security could help in mediating the SI-eG usage behaviour relationship.

Based on the statistical results, eG service UB has been found to have a positive, significant effect on eG CUB. Thus, hypothesis H7 was supported, as indicated in the 
study. These results indicate that the initial usage behaviour of eG services encourages the users to be more likely to have the intention to continue their usage of eG services in an unstable security context. The outcome of this study is in line with the study that shows a significant relationship among various variables and the CUI towards technology (Chiu and Wang, 2008; Hong et al., 2006).

\section{Limitations of the study}

Although this study has produced interesting findings, it does, however, have certain limitations; first, this study reports a limitation with respect to sample size and number of universities in the present study, which is relatively small. Additionally, this study targeted only the public universities employees in Iraq. Therefore, the findings of this study do not reflect the behaviour of other fields such as private universities, students, school teachers, agriculture sector, military sector and industrial sector. Also, this study focused on the investigations of the antecedents of usage and CUI in Iraq. Moreover, this study included other aspects such as the effects of infrastructure on public universities employees in a violent environment. Finally, this study discussed a few antecedents of eG and neglected a lot of them, such as the motivations, trust, service quality, website features and others.

\section{Directions for future research}

Limitations of this study could create opportunities for future research by increasing the sample size to be more comprehensive, and targeting other sectors, such as retired and private sector employees in Iraq. Future research could examine also more antecedents or factors influencing eG in Iraq since the variables are still recommended to be investigated on a larger scale by future research with specific attention being given to eG services. These variables could include trust, safety, readiness, enjoy, cost, time, security, motivations, service quality, resistance to change, website features and others.

Additionally, future research could conduct more related studies in eG settings in Iraq since there are only a few past studies investigating the eG in Iraq or a comparative study could be conducted to compare between Iraq and other countries using eG services. Since this study was based on UTAUT theory, future research could extend this theory and apply it in a new version in eG or other technology acceptance theories could be applied in the Iraqian context, such as TAM3, UTAUT2 and DeLone and McLean's model and others. In this study, the researcher used only one instrument, a questionnaire survey. Thus, the researcher suggested that the qualitative method in-depth interview could be a suitable way to find more factors that could influence eG services users towards eG in Iraq. This can be better achieved when the researcher builds a trusted relationship with them and speaks their language. The current study has targeted actual and CUI of users towards eG and reported the important features motivating their engagement in eG options in the Iraqi context. The same approach may also be applied to non-users in a quest for pointing out areas of design quality that needs improvement or increases interactivity to overcome non-users' apprehension. 


\section{Conclusions}

Most of the previous literature that examined UTAUT includes studies that have been conducted in developed countries, and very few studies have considered the context of developing countries. However, this study attempted to examine the UTAUT theory in an unstable security country, namely Iraq, in the Middle East region. Additionally, this study demonstrated that the UTAUT model can be valid and utilised to examine CUB towards eG services in diverse cultures.

In general, this study is considered to be one of very few studies conducted in the Arab world to validate the UTAUT theory as a framework to explain eG UB and CUI by integrating the effect of service awareness with other UTAUT variables. In addition, this study has contributed to the literature by examining the mediating effect of eG service usage behaviour between the UTAUT variables, namely EE, FCs, performance expectancy, and social influence, and eG service CUI.

In regards to implications, the findings of this study could be of great value for governments and their agents in promoting eG services among citizen's. As the study revealed, even though the IT infrastructure is very important in promoting eG services, the awareness of the individual of the services and the perception of how eG could make life easier can play a major role. This implies that the usage of eG services should be developed as a culture among citizen's by holding awareness and advertisement campaigns. It is also very crucial for governments to make eG services available for the citizen's to try and exercise a good experience that may lead them to choose to use eG services in their lifestyle.

Future research could further study the security perception of the citizen's as a mediating variable between social influence and eG services UB. Some other variables such as trust, safety, readiness, enjoyment, cost, time, security, motivations, service quality, resistance to change, website features, and others might be of great interest to the researchers to better understand the antecedents of eG service usage and CUBs.

\section{References}

Abdalla, S. (2012) An E-Government Adoption Framework for Developing Countries: A Case Study from Sudan, Doctoral dissertation, Cranfield University.

Abdul-Rahman, A., Jamaludin, A. and Mahmud, Z. (2011) 'Intention to use digital library based on modified UTAUT model: perspectives of Malaysian postgraduate students', World Academy of Science, Engineering and Technology, Vol. 75, No. 3, pp.116-122.

Abri, D.S.S.A. (2009) Examining the Impact of E-privacy Risk Concerns on Citizens' Intentions to use E-government Services: An Oman Perspective, Doctoral dissertation, Murdoch University.

Abu-Auf, M.A, Salleh, S.B.M. and Yusoff, R.Z. (2016) 'The relationship between word of mouth and consumer buying behavior mediating by religious orientation in Riyadh, Saudi Arabia', International Review of Management and Marketing, Vol. 6, No. 4, pp.1034-1038.

Adulwahab, L. and Dahalin, Z.M. (2011) 'Effectiveness of telecentre using a model of unified theory of acceptance and use of technology (UTAUT): structural equation modeling approach', Emerging Trends in Computing and Information Sciences, Vol. 2, No. 9, pp.402-406.

Ajzen, I. (1991) 'The theory of planned behavior', Organizational Behavior and Human Decision Processes, Vol. 50, No. 2, pp.179-211. 
Aladwani, A.M. (2016) 'Corruption as a source of e-government projects failure in developing countries', Int. J. Inf. Manag., Vol. 36, No. 1, pp.105-112, DOI: 10.1016/j.ijinfomgt.2015. 10.005 .

AlAwadhi, S. and Morris, A. (2008) 'The use of the UTAUT model in the adoption of e-government services in Kuwait', Proceedings of the 41st Annual Hawaii International Conference on System Sciences, Waikoloa, Hawaii, 7-10 January.

Al-Hakim, L.A.Y. (2012) Knowledge Management Implementation, Innovation, and Organisational Performance: An Empirical Study in the Iraqi Mobile Telecommunications Sector, $\mathrm{PhD}$ thesis, Universiti Utara Malaysia.

Al-Mutmar (2013) Call for the Adoption of E-Government to Curb Corruption [online] http://www.almutmar.com/index.php?id=20118340 (accessed 22 June 2016).

Alruwaie, M. (2012) 'A framework for evaluating citizens' outcome expectations and satisfactions toward continued intention to use e-government services', Paper presented at the Doctoral Symposium, Brunel Business School, London, UK.

Al-Salam, F. (2011) Minister of Science and Technology Mentions about EG Portal Soon will Exist [online] http://wafnews.com/index.php/permalink/3297.html (accessed 28 June 2016).

Al-Shafi, S. and Weerakkody, V. (2009) 'Understanding citizens' behavioural intention in the adoption of e-government services in the state of Qatar', ECIS 2009 Proceedings, p.430 [online] http://aisel.aisnet.org/ecis2009/430.

Al-Shafi, S. and Weerakkody, V. (2010) 'Factors affecting e-government adoption in the state of Qatar', Paper presented at the European and Mediterranean Conference on Information Systems, pp.1-23.

Alshehri, M., Drew, S., Alhussain, T. and Alghamdi, R. (2012) 'The effects of website quality on adoption of e-government service: an empirical study applying UTAUT model using SEM', Paper presented at the 23rd Australasian Conference on Information Systems, Geelong.

AlShihi, H. (2006) Critical Factors in the Adoption and Diffusion of E-government Initiatives in Oman, Doctoral dissertation, Victoria University.

Al-Sobhi, F., Weerakkody, V. and El-Haddadeh, R. (2011) 'The roles of intermediaries in e-government adoption: the case of Saudi Arabia', Paper presented at the Gov. Workshop11, West London, pp.1-13.

Alsohybe, N.T. (2007) The Implementation of E-Government in the Republic of Yemen: An Empirical Evaluation of the Technical and Organizational Readiness, Doctoral dissertation, Proquest Dissertations and Theses, Capella University.

Alsyouf, A. and Ishak, A.K. (2018) 'Understanding EHRs continuance intention to use from the perspectives of UTAUT: practice environment moderating effect and top management support as predictor variables', Int. J. of Electronic Healthcare, Vol. 10, Nos. 1/2, DOI: 10.1504/ IJEH.2018.10013367.

Alvesson, M. and Karreman, D. (2007) 'Constructing mystery: empirical matters in theory development', Academy of Management Review, Vol. 32, No. 4, pp.1265-1281.

Bagozzi, R.P. and Yi, Y. (1988) 'On the evaluation of structural equation models', Journal of the Academy of Marketing Science, Vol. 16, No. 1, pp.74-94.

Barclay, D., Higgins, C. and Thompson, R. (1995) 'The partial least square (PLS) approach to casual modeling: personal computer adoption and use as an illustration', Technology, Vol. 2, No. 2, pp.285-309.

Basu, S. (2004) 'E-government and developing countries: an overview', International Review of Law Computers Technology, Vol. 18, No. 1, pp.109-132.

Berlilana, Hariguna, T. and Nurfaizah (2017) 'Understanding of public behavioral intent to use e-government service: an extended of unified theory of acceptance use of technology and information system quality', Procedia Computer Science, Vol. 124, pp.585-592, DOI: https://doi.org/10.1016/j.procs.2017.12.193 [online] https://www.sciencedirect.com/ science/article/pii/S1877050917329617. 
Beynon-Davies, P and Williams, D (2004) 'Evaluating electronic local government in the UK', Journal of Affairs, Vol. 57, No. 2, pp.269-287.

Bhattacherjee, A. (2001) 'Understanding information systems continuance: an expectation-confirmation model', MIS Quarterly, Vol. 25, pp.351-370, DOI: 10.2307/ 3250921.

Carlsson, C. and Carlsson, J. (2006) 'Adoption of mobile device/services - searching for answers with the UTAUT', Hawaii International Conference on System Sciences, Hawaii.

Carter, L. and Belanger, F. (2004) 'Citizen adoption of electronic government initiatives', Paper presented at the 37th Hawaii International Conference on System Sciences.

Carter, L. and Belanger, F. (2005) 'The utilization of e-government services: citizen trust, innovation and acceptance factors', Information Systems Journal, Vol. 15, No. 1, pp.5-25, DOI: $10.1111 / \mathrm{j} .1365-2575.2005 .00183 . \mathrm{x}$

Carter, L. and Bishath, W. (2008) 'E-government adoption: a cultural comparison', Inf. Syst. Front., Vol. 10, No. 4, pp.473-482.

Chan, C.M.L., Lau, Y. and Pan, S.L. (2008) 'E-government implementation: a macro analysis of Singapore's e-government initiatives', Government Information Quarterly, Vol. 25, No. 2, pp.239-255.

Chiu, C.M. and Wang, E.T.G. (2008) 'Understanding web-based learning continuance intention: the role of subjective task value', Information \& Management, No. 45, pp.194-201, DOI: 101016/j.im2008.02.003.

Chou, Y-H.D., Li, T-Y.D. and Ho, C-T.B. (2018) 'Factors influencing the adoption of mobile commerce in Taiwan', International Journal of Mobile Communications, Vol. 16, No. 2, pp.117-134.

Chu, P-Y., Hsiao, N., Lee, F-W. and Chen, C-W. (2004) 'Exploring success factors for Taiwan's government electronic tendering system: behavioral perspectives from end users', Government Information Quarterly, Vol. 21, pp.219-234 [online] http://dx.doi.org/10.1016/j.giq.2004.01. 005 .

Compeau, D.R. and Higgins, C.A. (1995) 'Computer self-efficacy: development of a measure and initial test', MIS Quarterly, Vol. 19, No. 2, pp.89-211.

Cooper, R.B. and Zmud, R.W. (1990) 'Information technology implementation research: a technological diffusion approach', Management Science, Vol. 36, No. 2, pp.123-139.

Davis, F.D. and Bagozzi, R.P. (1989) 'User acceptance of computer technology: a comparison of two theoretical models', Management Science, Vol. 35, No. 8, pp.982-1003.

Davis, F.D., Bagozzi, R.P. and Warshaw, P.R. (1992) 'Extrinsic and intrinsic motivation to use computers in the workplace', Journal of Applied Social Psychology, Vol. 22, No. 14, pp.1111-1132.

Davison, R.M., Wagner, C. and Ma, L.C.K. (2005) 'From government to e-government: a transition model', Information Technology \& People, Vol. 18, pp.280-299, DOI: 10.1108/ 09593840510615888.

Ebrahim, Z. and Irani, Z. (2005) 'E-government adoption: architecture and barriers', Business Process Management, Vol. 11, No. 5, pp.589-611.

Evans, D. and Yen, D.C. (2005) 'E-government: an analysis for implementation: framework for understanding cultural and social impact', Government Information Quarterly, Vol. 22, No. 3, pp.354-373.

Fairchild, A.J. and McQuillin, S.D. (2010) 'Evaluating mediation and moderation effects in school psychology: a presentation of methods and review of current practice', Journal of School Psychology, Vol. 48, No. 1, pp.53-84 [online] http://dx.doi.org/10.1016/j.jsp.2009.09.001.

Fishbein, M. and Ajzen, I. (1975) Belief, Attitude, Intention, and Behavior: An Introduction to Theory and Research, Addison-Wesley, Reading, MA. 
Foon, Y.S. and Fah, B.C.Y. (2011) 'Internet banking adoption in Kuala Lumpur: an application of UTAUT model', International Journal of Business and Management, Vol. 6, No. 4, pp.161-167.

Fornell, C. and Cha, J. (1994) 'Partial least squares', in Bagozzi, R.P. (Ed.): Advanced Methods of Marketing Research, pp.52-78, Blackwell, Cambridge, MA.

Fornell, C. and Larcker, D.F. (1981) 'Evaluating structural equation models with unobservable variables and measurement error', Journal of Marketing Research, Vol. 18, No. 1, pp.39-50.

Graafland-Essers, I. and Ettedgui, E. (2003) Benchmarking e-Government in Europe and the US, pp.14-11 [online] https://www.google.co.uk/url?sa=t\&rct=j\&q=\&esrc=s\&source=web\&cd= $1 \&$ cad $=$ rja $\&$ ved $=0 \mathrm{CDYQFjAA} \& u r l=\mathrm{http} \% 3 \mathrm{~A} \% 2 \mathrm{~F} \% 2 \mathrm{Fwww}$.rand.org $\% 2 \mathrm{~F}$ content $\% 2 \mathrm{Fdam} \%$ 2Frand\%2Fpubs\%2Fmonograph_reports\%2F2005\%2FMR1733.pdf\&ei= wLKUrTyDsnprAf OyYGoCA\&usg=AFQjCNEhvYzJRVJ0x3oFZYrdMaGtcqtgGw\&bvm=ㅎv.58187178,d.bmk (accessed 28 June 2016).

Griffin, D. and Halpin, E. (2005) 'An exploratory evaluation of UK local e-government from an accountability perspective', Electronic Journal of e-Government, Vol. 3, No. 1, pp.13-28.

Griffin, D. and Halpin, E. (2005) 'An exploratory evaluation of UK local e-government from an accountability perspective', Electronic Journal of e-Government, Vol. 3, No. 1, pp.13-28.

Hair, J.F., Black, W.C., Babin, B.J. and Anderson, R.E. (2010) Multivariate Data Analysis, 7th ed.

Hair, J.F., Hult, G.T.M., Ringle, C.M. and Sarstedt, M. (2017) A Primer on Partial Least Squares Structural Equation Modeling (PLS-SEM), 2nd ed., Thousand Oaks, Sage.

Hamilton, F., Pavan, P. and Mchale, K. (2011) 'Designing usable e-government services for the citizen-success within user centred design', International Journal of Public Information Systems, Vol. 3, pp.159-167 [online] http://www.ijpis.net/ojs/index.php/IJPIS/article/ viewFile/93/88.

Heeks, R. (2008) Success and Failure Rates of eGovernment in Developing/Transitional Countries: Overview [online] http://www.egov4dev.org/success/sfrates.shtml (accessed 25 June 2016).

Heidelberger Institut für Internationale Konfliktforschung (HIIK) (2008) 'Conflict barometer: crises - wars - coups d' etat negotiations - mediations - peace settlements', 17th Annual Conflict Analysis, Heidelberg Institute For International Conflict Research at the Department of Political Science, University of Heidelberg, Heidelberg.

Helena, C.Y-T. and Maria, H.K. (2015) 'Service innovation and usage intention: a cross-market analysis', Journal of Service Management, Vol. 26, No. 3, pp.516-538, DOI: doi:10.1108/ JOSM-10-2014-0274.

Henseler, J., Ringle, C.M. and Sarstedt, M. (2014) 'A new criterion for assessing discriminant validity in variance-based structural equation modeling', Journal of the Academy of Marketing Science, Vol. 43, No. 1, pp.115-135, DOI: 10.1007/s11747-014-0403-8.

Holden, S.H., Norris, D.F. and Fletcher, P.D. (2003) 'Electronic government at the local level: progress to date and future issues', Public Performance \& Management Review, Vol. 26, No. 4, pp.325-344.

Hong, S., Thong, J.Y.L. and Tam, K.Y. (2006) 'Understanding continued information technology usage behavior: a comparison of three models in the context of mobile internet', Decision Support Systems, Vol. 42, pp.1819-1834 [online] http://dx.doi.org/10.1016/j.dss.2006.03.009.

Horst, M., Kuttschreuter, M. and Gutteling, J.M. (2007) 'Perceived usefulness, personal experiences, risk perception and trust as determinants of adoption of e-government services in The Netherlands', Computers in Human Behavior, Vol. 23, pp.1838-1852, [online] http://dx.doi.org/10.1016/j.chb.2005.11.003.

$\mathrm{Hu}$, L. and Bentler, P.M. (1998) 'Fit indices in covariance structure modeling: sensitivity to underparameterized model misspecification', Psychological Methods, Vol. 3, No. 4, pp.424-453. 
Hu, L. and Bentler, P.M. (1999) 'Cutoff criteria for fit indexes in covariance structure analysis: conventional criteria versus new alternatives', Structural Equation Modeling, Vol. 6, No. 1, pp.1-55.

Hujran, O.A. and Shahateet, M. (2010) 'Citizen adoption of e-government initiatives in developing countries: a case study of Jordan', Paper presented at the 10th European Conference on eGovernment Limerick Ireland.

Hung, S.Y., Chang, C.M. and Yu, T.J. (2006) 'Determinants of user acceptance of e-government services: the case of online tax filing and payment system', Government Information Quarterly, Vol. 23, No. 1, pp.97-122.

IRAQ e-GOV Portal (2012) IRAQ e-GOV Portal [online] http://www.egov.gov.iq/egoviraq/index.jsp?\&lng=ar (accessed 14 April 2012).

Jaeger, P.T. and Thompson, K.M. (2003) 'E-government around the world: lessons, challenges, and future directions', Government Information Quarterly, Vol. 20, No. 4, pp.389-394.

Karahanna, E., Straub, D.W. and Chervany, N.L. (1999) 'Information technology adoption across time: a cross-sectional comparison of pre-adoption and post-adoption beliefs', MIS Quarterly, Vol. 23, pp.183-213, DOI: 10.2307/249751.

Kenny, D.A. and Little, T.D. (2011) Methodology in the Social Sciences, 3rd ed., The Guilford Press, New York.

Khan, G.F. (2010) Essays on Electronic Government in Developing Countries: A Socio-Technical Perspective, Doctoral dissertation, Kaist University.

Khan, G.F., Moon, J., Swar, B., Zo, H. and Rho, J.J. (2010b) 'E-government service use intentions in Afghanistan: technology adoption and the digital divide in a war-torn country', Information Development, Vol. 28, No. 4, pp.281-299, DOI: 10.1177/0266666912438879.

Khan, G.F., Moon, J., Zo, H. and Rho, J.J. (2010a) 'Civil conflict, digital divide, and e-government service adoption: a conflict theory approach', World Academy of Science, Engineering and Technology, Vol. 66, pp.537-549 [online] https://www.safetylit.org/citations/index.php? fuseaction $=$ citations. viewdetails\&citationIds[] $=$ citjournalarticle_394829_38.

Khan, G.F., Moon, J., Zo, H. and Rho, J.J. (2012) E-government Service Use Intention: Digital Divide and Technology Adoption in a War-torn Country Information Development.

Kijsanayotin, B., Pannarunothai, S. and Speedie, S.M. (2009) 'Factors influencing health information technology adoption in Thailand's community health centers: applying the UTAUT model', International Journal of Medical Informatics, Vol. 78, pp.404-416, DOI: 10.1016/j.ijmedinf.2008.12.005

Kline, R.B. (2011) in Teo, T.S.H. (Ed.): Principles and Practice of Structural Equation Modeling, Guilford Press, New York.

Krishnan, S., Teo, T.S.H. and Lymm, J. (2017) 'Determinants of electronic participation and electronic government maturity: Insights from cross-country data', International Journal of Information Management, Vol. 37, No. 4, pp.297-312.

Kumar, R. and Best, M.L. (2006) 'Impact and sustainability of e-government services in developing countries: lessons learned from Tamil Nadu, India', The Information Society, Vol. 22, No. 1, pp.1-12, DOI: 10.1080/01972240500388149.

Lawan, A. (2009) Amodification of Unified Theory of Acceptance and Use of Technology (UTAUT) From User's Perspectives of Telecentre in Nigeria, Doctoral dissertation.

Lean, O.K., Zailani, S., Ramayah, T. and Fernando, Y. (2009) 'Factors influencing intention to use e-government services among citizens in Malaysia', International Journal of Information Management, Vol. 29, No. 6, pp.458-475.

Lee, J.K., Braynov, S. and Rao, R. (2003) 'Effects of public emergency on citizens' usage intention toward e-government: a study in the context of war in Iraq', Paper presented at the International Conference on Information Systems (ICIS). 
Limayem, M., Hirt, S.G. and Cheung, C.M.K. (2003) 'Habit in the context of IS continuance: theory extension and scale development', Paper presented at the ECIS.

Ma, L., Chung, J. and Thorson, S. (2005) 'E-government in China: bringing economic development through administrative reform', Government Information Quarterly, Vol. 22, No. 1, pp.20-37.

MacKinnon, D.P. and Fairchild, A.J. (2010) 'Current directions in mediation analysis', Curr. Dir. Psychol. Sci., Vol. 18, No. 1, DOI: 10.1111/j.1467-8721.2009.01598.x.

Maldonado, U.P.T., Khan, G.F., Moon, J. and Rho, J.J. (2011) 'E-learning motivation and educational portal acceptance in developing countries', Online Information Review, Vol. 35, No. 1, pp.66-85.

Marchewka, J.T., Liu, C. and Kostiwa, K. (2007) 'An application of the UTAUT model for understanding student perceptions using course management software', Communications of the IIMA, Vol. 7, No. 2, pp.93-104.

Meer, V.D. and Winden, V. (2003) 'E-governance in cities: a comparison of urban information and communication technology policies regional studies', The Journal of the Regional Studies Association, Vol. 37, pp.407-419.

Mofleh, S.I. and Wanous, M. (2008) 'Understanding factors influencing citizens' adoption of e-government services in the developing world: Jordan as a case study', Journal of Computer Science, Vol. 7, pp.1-11.

Moon, M.J. and Norris, D.F. (2005) 'Does managerial orientation matter? The adoption of reinventing government and e-government at the municipal level', Information Systems Journal, Vol. 15, No. 1, pp.43-60, DOI: 10.1111/j.1365-2575.2005.00185.x.

National Strategy and Action Plan E-governance in Iraqi (2012-2015) National Strategy and Action Plan E-governance in Iraqi 2012-2015.

Oliveira, T., Faria, M. and Thomas, M.A. (2014) 'Extending the understanding of mobile banking adoption: When UTAUT meets TTF and ITM', Int. J. Inf. Manag., Vol. 34, No. 5, pp.689-703, DOI: 10.1016/j.ijinfomgt.2014.06.004.

Ovčjak, B., Heričko, M. and Polančič, G. (2015) 'Factors impacting the acceptance of mobile data services - a systematic literature review', Computers in Human Behavior, Vol. 53, pp.24-47, DOI: http://dx.doi.org/10.1016/j.chb.2015.06.013 [online] https://www.sciencedirect.com/ science/article/pii/S0747563215004525.

Ozkan, S. and Kanat, I.E. (2011) E-government adoption model based on theory of planned behaviour empirical validation', Government Information Quarterly, Vol. 28 pp.503-513 [online] http://dx.doi.org/10.1016/j.giq.2010.10.007.

Park, R. (2008) 'Measuring factors that influence the success of e-government initiatives', Paper presented at the Hawaii International Conference on System Sciences, Proceedings of the 41st Annual, pp.1530-1605.

Phang, C.W., Sutanto, J., Li, Y. and Kankanhalli, A. (2005) 'Senior citizens' adoption of e-government: in quest of the antecedents of perceived usefulness', Paper presented at the 38th Hawaii International Conference on System Sciences.

Prima, S. and Ibrahim, R.B. (2011) 'Citizen awareness to e-government services for information personalization', International Journal of Innovative Computing, Vol. 1, No. 1.

Raffaele, F., Wenshin, C. and Bidit, L.D. (2017) 'The importance of enhancing, maintaining and saving face in smartphone repurchase intentions of Chinese early adopters: an exploratory study', Information Technology \& People, Vol. 30, No. 3, pp.629-652, DOI: doi:10.1108/ITP09-2015-0230.

Raman, M., Stephenaus, R., Alam, N. and Kuppusamy, M. (2008) 'Information technology in Malaysia: e-service quality and Uptake of Internet banking', Journal of Internet Banking \& Commerce, Vol. 13, No. 2, pp.1-18.

Reyes-Mercado, P. (2018) 'Adoption of fitness wearables: Insights from partial least squares and qualitative comparative analysis', Journal of Systems and Information Technology, Vol. 20, No. 1, pp.103-127, DOI: 10.1108/JSIT-04-2017-0025.

Rogers, E.M. (2003) Diffusion of Innovations, 5th ed., Free Press. 
Rokhman, A. (2011) 'E-government adoption in developing countries; the case of Indonesia', Journal of Emerging Trends in Computing and Information Sciences, Vol. 2, No. 5, pp.228-236.

Roy, M-C., Chartier, A., Crête, J. and Poulin, D. (2015) 'Factors influencing e-government use in non-urban areas', Electronic Commerce Research, Vol. 15, pp.349-363, DOI: 10.1007/ s10660-015-9193-4.

Shaikh, A.A. and Karjaluoto, H. (2015) 'Making the most of information technology systems usage: a literature review, framework and future research agenda', Computers in Human Behavior, Vol. 49, pp.541-566 [online] http://dx.doi.org/10.1016/j.chb.2015.03.059.

Shamsuddin, J., Sarkawi, M.N., Jaafar, A.R. and Rahim, N.F.A. (2017) 'Malaysian SMEs performance and the government business support service: the moderating effects of absorptive capacity', International Journal of Supply Chain Management, Vol. 6, No. 4, pp.326-331.

Siau, K. and Long, Y. (2005) 'Synthesizing e-government stage models - a meta-synthesis based on meta-ethnography approach', in Abdulla et al. (Eds.): Industrial Management \& Data Systems, Vol. 105, No. 4, pp.443-458.

Taylor, S. and Todd, P. (1995) 'Assessing IT usage: the role of prior experience', MIS Quarterly, Vol. 19, No. 4, pp.561-570.

Teo, T.S.H., Srivastava, S.C. and Jiang, L. (2009) 'Trust and electronic government success: an empirical study', in Oliveira et al. (Eds.): Management Information Systems, Vol. 25, No. 3, pp.99-131.

The World Bank Group (2002) E-Government Definition, Washington, DC [online] http://documents.worldbank.org/curated/en/527061468769894044/pdf/266390WP0E1Gov1ge ntina1Final1Report.pdf (accessed 25 June 2016).

Thompson, R.L., Higgins, C.A. and Howell, J.M. (1991) 'Personal computing: toward a conceptual model of utilization', MIS Quarterly, Vol. 15, No. 1, pp.125-143.

Top 10 Most Dangerous Countries in the World (2013) Top 10 Most Dangerous Countries in the World 2013 [online] http://toptenstore.blogspot.com/2013/01/top-10-most-dangerouscountries-in.html (accessed 4 August 2013).

UN and ESCWA (2007) National Profile of the Information Society in Iraq.

United Nations (2003) World Public Sector Report 2003, New York.

United Nations (2004) Global E-Government Readiness Report 2004, New York.

United Nations (2005) UN Global E-government Readiness Report 2005.

United Nations (2008) United Nations e-Government Survey 2008, New York.

United Nations (2012) E-Government Survey 2012, p.143, Department of Economic and Social Affairs, New York.

Venkatesh, V. and Davis, F.D. (2000) 'A theoretical extension of the technology acceptance model: four longitudinal field studies', Management Science, Vol. 46, No. 2, pp.186-204.

Venkatesh, V., Morris, M.G., Davis, G.B. and Davis, F.D. (2003) 'User acceptance of information technology: toward a unified view1', MIS Quarterly, Vol. 27, No. 3, pp.425-478.

Venkatesh, V., Sykes, T. and Zhang, X. (2011) 'Just what the doctor ordered: a revised UTAUT for EMR system adoption and use by doctors', Proceedings of the 44th Hawaii International Conference on System Sciences, Kauai, HI., USA, pp.1-10.

Venkatesh, V., Thong, J.Y.L. and Xu, X. (2012) 'Consumer acceptance and use of information technology: extending the unified theory of acceptance and use of technology', MIS Quarterly, Vol. 36, No. 1, pp.157-178.

Wang, Y.S. and Shih, Y.W. (2009) 'Why do people use information kiosks? A validation of the unified theory of acceptance and use of technology', Government Information Quarterly, Vol. 26, No. 1, pp.158-165, DOI: 10.1016/j.giq.2008.07.001.

Wang, Y-S. (2002) 'The adoption of electronic tax filing systems: an empirical study', Government Information Quarterly, Vol. 20, No. 4, pp.333-352. 
Wangpipatwong, S., Chutimaskul, W. and Papasratorn, B. (2008) 'Understanding citizen's continuance intention to use e-government website: a composite view of technology acceptance model and computer self-efficacy', The Electronic Journal of e-Government, Vol. 6, No. 1, pp.55-64.

Weerakkody, V., El-Haddadeh, R., Al-Sobhi, F., Shareef, M.A. and Dwivedi, Y.K. (2013) 'Examining the influence of intermediaries in facilitating e-government adoption: an empirical investigation', International Journal of Information Management, Vol. 33, No. 5, pp.716-725.

Wu, Y.L. and Tao, Y.H. (2007) 'Using UTAUT to explore the behavior of 3G mobile communication users', Industrial Engineering and Engineering Management, 2007 IEEE International Conference, pp.199-203.

Yahya, M., Nadzar, F., Masrek, N. and Abd Rahman, B. (2011) 'Determinants of UTAUT in measuring user acceptance of E-Syariah portal in Syariah courts in Malaysia', Proceedings of the 2nd International Research Symposium in Service Management, Yogyakarta, Indonesia, 26-30 July, pp.242-250.

Yun, H.J. and Opheim, C. (2010) 'Building on success: the diffusion of e-government in the American States', Electronic Journal of e-Government, Vol. 8, No. 1, pp.71-82.

Yusr, M.M., Mokhtar, S.S.M., Othman, A.R. and Sulaiman, Y. (2017) 'Does interaction between TQM practices and knowledge management processes enhance the innovation performance?', International Journal of Quality \& Reliability Management, Vol. 34, No. 7, pp.955-974. 